\title{
RADIKALISME AGAMA DAN UPAYA DERADIKALISASI PEMAHAMAN KEAGAMAAN
}

\author{
Muhammad Harfin Zuhdi \\ Universitas Islam Negeri Mataram \\ Jl. Pendidikan, Nusa Tenggara Barat, 83125, Indonesia \\ E-mail:harfin72@yahoo.co.id
}

\begin{tabular}{l|l|l}
\hline Received: & Revised: & Approved: \\
16/03/2017 & $22 / 06 / 2017$ & $23 / 06 / 2017$ \\
\hline
\end{tabular}

\begin{abstract}
Abstrak
Fenomena radikalisme agama merupakan persoalan yang berhubungan dengan pengalaman inti, memori kolektif dan penafsiran agama. secara umum setiap agama memiliki dua fungsi: pertama, fungsi manifest, yaitu fungsi yang disadari betul oleh para pengikutnya sebagai manifestasi objektif dari suatu sistem sosial, misalnya meningkatkan kehesivitas umat (ukuwah islamiyah). Kedua, fungsi laten, yaitu fungsi yang tidak dikehendaki secara sadar dari sistem sosial tersebut dalam memunculkan radikalisme, dan agama merupakan lahan empuk untuk menjadi crying banner dalam melakukan tindakan radikalisme. Dalam konteks agama Islam, salah satu penyebabnya adalah pemahaman yang keliru atas ayat-ayat al-Qur'an dan juga hadis Nabi tentang jihad dan perang. Tulisan ini bermaksud mendeskripsikan wacana radikalisme agama dan untuk menelaah ayat-ayat tersebut dengan memerhatikan makna dan konteks kesejarahannya sehingga dihasilkan pemahaman yang benar dan komprehensif. Hasil penelaahan memberikan kesimpulan
\end{abstract}


bahwa jihad dan qital dalam al-Qur'an berbeda dengan tindakan radikalisme.

Kata kunci: radikalisme, jihad, dan qital.

\section{Abstract}

The phenomenon of religious radicalism is a matter related to core experience, collective memory and religious interpretation. In general, every religion has two functions: first, the manifest function is a function that its followers perceive as an objective manifestation of a social system, for example increasing the dignity of the ummah (ukuwah islamiyah). Secondly, latent functions, the unwittingly conscious function of the social system in generating radicalism, and religion is a soft field to become a crying banner in the conduct of radicalism. In the context of Islam, one of the reasons is the missunderstanding of the verses of Qur'an and the traditions of the Prophets of jihad and war (qital). This paper aims to describe the discourse of religious radicalism and to review these verses with regard to the meaning and historical context that result the correct and comprehensive understanding. This article concludes that jihad and war (qital) in the Qur'an is different from the act of radicalism.

Keywords: Radicalism, Jihad, and War

\section{A. Pendahuluan}

Sejak kemunculan istilah fundamentalisme agama, istilah radikalisme juga menyeruak sebagai fenomena agama dalam satu dekade terakhir. Apa yang dimaksud dengan radikalisme lebih merujuk pada fenomena aksi kekerasan oleh kelompok tertentu dengan membawa legitimasi agama di dalamnya.

Secara umum, fenomena radikalisme saat ini semakin marak terjadi dalam realitas kehidupan. Berbagai 
demonstrasi, apakah itu bermuatan politik, sosial, ekonomi, budaya, dan agama mewarnai kehidupan masyarakat. Persoalan-persoalan tersebut cenderung direspon dengan tindakan kekerasan, yang dalam banyak hal justru kontraproduktif. Salah satu implikasinya adalah kekerasan yang dikonstruk sebagai radikalisme menjadi variabel dominan dalam berbagai tindakan kekerasan yang mengatasnamakan agama. Agama yang semula bermisi kedamaian tereduksi dengan tindakan-tindakan yang bertentangan dengannya. ${ }^{1}$

Pengaruh radikalisme agama dapat melahirkan radikalisasi gerakan keagamaan yang menurut Endang Turmudzi akibat adanya kenyataan dari menguatnya fundamentalisme keberagamaan para pemeluknya yang disebabkan oleh keinginan kuat untuk mempraktekkan doktrin ajaran agamanya yang dalam bentuk gambaran masyarakat ideal dan tantangan realitas domestik umat dalam negeri dan konstelasi politik internasional yang dinilai memojokkan dan merusak kehidupan sosial politik umat Islam. ${ }^{2}$

Kemunculan dan perkembangan gerakan radikal di Indonesia tidak terlepas dari pasca pergantian Orde Baru berganti menjadi Orde Reformasi, di mana masa itu terdapat banyak faham, pemikiran dan gerakan yang diekpresikan oleh organisasi keagamaan yang menunjukkan semangat keberagamaan umat sebagai cerminan aktualisasi dan sekaligus keinginan kuat untuk memperbaiki keadaan umat. Sekedar menyebut contoh beberapa ormas yang secara lantang menyuarakan ide-ide

1 Nur Syam, "Radikalisme dan Masa Depan Hubungan Agama-Agama: Rekonstruksi Tafsir Sosial Agama" (Tidak dipublikasikan, 10 Oktober 2005).

2 Endang Turmudzi dan Riza Sihbudi, Islam dan Radikalisme di Indonesia (Jakarta: LIPI Press, 2005), 1-8. 
tersebut, seperti Majelis Mujahidin Indonesia (MMI), Hizbut Tahrir Indonesia (HTI), Front Pembela Islam (FPI) dan Laskar Jihad. ${ }^{3}$ Mereka menyuarakan isu-isu agama yang cenderung "keras" sebagai bagian dari upaya negosiasi dalam merumuskan tatanan sosial yang baru. ${ }^{4}$

\section{B. Radikalisme: Makna dan Latar Kemunculannya}

Secara etimologi, terma radikalisme berasal akar kata radix, yang artinya bertindak radikal dan dapat juga berarti sampai ke akar-akarnya. ${ }^{5}$ Berpikir secara radikal sama artinya dengan berpikir hingga ke akar-akarnya, hal tersebutlah yang kemudian besar kemungkinan bakal menimbulkan sikap-sikap anti kemapanan. Dengan demikian, radikalisme dapat dipahami sebagai suatu sikap atau posisi yang mendambakan perubahan terhadap status quo dengan jalan menghancurkannya secara total, dan menggantinya dengan seseuatu yang baru, yang sama sekali berbeda. Biasanya cara yang digunakan bersifat

3 Lahirnya gerakan radikalisme di Indonesia diakui tidak bisa dilepaskan dari pengaruh gerakan radikal Islam di Timur Tengah. Pengaruh dari gerakan di Timur Tengah itu dapat dilihat dari adanya kesamaan idola tokoh, ideologi, metode pembinaan dan organisasi. Dari sisi tokoh utama gerakan radikal Islam Indonesia sebagian besar adalah keturunan Arab Yaman (biasa disebut Hadramaut), seperti Abu Bakar Ba'ashir (Amir Majelis Mujahidin Indonesia), Habib Rizieq Shihab (FPI), Ja'far Umar Thalib (Panglima Laskar Jihad), dan Secara geneologis tokohtokoh ini sedikit banyak memiliki karakter Arab Yaman yang terkenal dengan sikap keras dan tegas. Lihat, Deny Suito, Radikalime di Dunia Islam (Jakarta: CMM, 2005), 164.

4 Djamhari Makruf, "Radikalisme Islam di Indonesia; Fenomena Sesaat?," in Agama dan Radikalisme di Indonesia (Jakarta: Huqtah, 2007), 26.

5 John M. Echols dan Hassan Shadily, "Kamus Inggris Indonesia" (Jakarta: Gramedia, 1995). 
revolusioner, artinya menjungkirbalikkan nilai-nilai yang ada secara drastis lewat kekeraan (violence) dan aksi-aksi yang ekstrim. ${ }^{6}$

Dalam bahasa Arab, term radikalisme disebut dengan beberapa istilah, antara lain al-'unf, at-tatarruf, dan alguluww. Al-'unf adalah tindakan kekerasan dengan penggunaan kekuatan secara ilegal (main hakim sendiri) untuk memaksanakan kehendak dan pendapat. ${ }^{7}$ Al-tatarruf secara bahasa berasal dari kata al-tarf yang mengandung arti "ujung atau pinggir". Artinya berada pada posisi ujung atau pinggir, baik di ujung kiri maupun kanan. Karenanya, kata ini bermakna radikal, ekstrem, dan berlebihan. ${ }^{8}$ Dengan demikian, al-tatarruf al-dini berarti segala perbuatan yang berlebihan dalam beragama, yang merupakan lawan kata dari al-wasath (tengah/moderat) yang memiliki makna baik dan terpuji. ${ }^{9}$

Berdasarkan makna tersebut, maka dapat dirumuskan bahwa radikalisme merupakan faham (isme), tindakan yang melekat pada seseorang atau kelompok yang menginginkan perubahan baik, sosial, politik dengan menggunakan kekerasan, berfikir asasi dan bertindak ekstrim. Di samping itu, radikalisme berlandaskan pada paradigma yang bersifat ekslusif, meniadakan orang lain

${ }^{6}$ Marx Juergensmeyer, Teror Atas Nama Tuhan : Kebangkitan Global kekerasan Agama (Jakarta: Nizam Press \& Anima Publishing, 2002), 5.

${ }^{7}$ Lajnah Pentashihan Mushaf al-Qur'an Kementerian Agama, Tafsir al-Qur'an Tematik, Jilid I (Jakarta: Kamil Pustaka, 2014), 97.

${ }^{8}$ Muchlis M. Hanafi, "Konsep al-Wasathiyyah dalam Islam," Harmoni: Jurnal Multikultural dan MultireligiusJurnal Multikultural dan Multireligius Puslitbang Kehidupan Keagamaan Badan Litbang dan Diklat Departemen Agama RI Jakarta VIII, no. 32 (OktoberDesember 2009): 39.

${ }^{9}$ Dede Rodin, "Islam dan Radikalisme: Telaah atas Ayat-ayat 'kekerasan' dalam al-Qur'an," Jurnal ADDIN 10, no. 1 (2016): 35. 
(the other), rigid, tertutup, ekstrimisme dan tidak jarang bersifat militeristik. ${ }^{10}$

Radikalisme memiliki istilah yang beragam, ada yang menyebut radikalisme dengan istilah fundamentalisme, ada pula yang menyebutnya sebagai ekstrimisme bahkan ada pula yang mengaitkannya dengan terorisme. Penamaan ini disebabkan karena makna yang terkandung dalam istilahistilah tersebut hampir sama. Jika radikalisme disebut sebagai paham yang cenderung menggunakan jalan kekerasan, maka istilah fundamentalisme dimaknai sebagai paham yang cenderung untuk memperjuangkan sesuatu secara radikal. ${ }^{11}$ Sedangkan ekstrimisme dimaknai sebagai paham yang cenderung ekstrim (keras). ${ }^{12}$ Selanjutnya istilah terorisme sering pula dikaitkan dengan radikalisme karena terorisme mengandung makna penggunaan kekerasan untuk menimbulkan rasa takut dalam usaha mencapai suatu tujuan. ${ }^{13}$

Berkaitan dengan hal ini, maka terdapat relasi antara potensi berpikir, bersikap dan bertindak radikal. Berideologi radikal (radikalisme) dan tumbuh reaktif menjadi radikal (radikalisasi) adalah modal awal seseorang menjadi pelaku teror (teroris) atau orang yang berpaham teror (terorisme). Tidak ada teror tanpa radikalisme. Sebaliknya penganut radikalisme belum tentu menyukai jalan kekerasan (teror). Sekalipun demikian, terdapat kesamaan bahasa yang digunakan oleh radikalisme

10 Bahtiar Effendi dan Hendro Prasetyo, ed., Radikalisme Agama (Jakarta: PPIM-IAIN, 1998), xvi.

11 Departemen Pendidikan dan Kebudayaan, "Kamus Besar Bahasa Indonesia" (Jakarta: Balai Pustaka, 1995), 281.

12 Ibid., 255.

${ }^{13}$ Ibid., 1048. 
maupun terorisme,yaitu bahasa militan atau bahasa perjuangan (language of militance). ${ }^{14}$

Secara filosofis, fenomena radikalisme agama merupakan persoalan yang berhubungan dengan pengalaman inti (core experience), memori kolektif (collective memory) dan penafsiran (interpretation) agama. ${ }^{15}$ Dalam konteks keagamaan, nampaknya istilah radikalisme hingga kini belum ada kesepakatan mengenai istilah yang tepat untuk menggambarkan gerakan radikal. ${ }^{16}$ Oliver Roy misalnya, menyebut gerakan Islam yang berorientasi pada pemberlakuan syariat Islam sebagai Islam fundamentalis, yang ditunjukkan dengan gerakan Ikhwanul Muslimin, Hizbut Tahrir, Jami'ati Islami dan Islamic Salvation Front (FIS). ${ }^{17}$ John L. Esposito lebih memilih menggunakan istilah revivalisme Islam atau aktivisme Islam, yang memiliki akar tradisi Islam. ${ }^{18}$ Muhammad Abid al-Jabiri menggunakan istilah ekstremisme Islam. ${ }^{19}$

Untuk lebih memperjelas fenomena radikalisme agama, kerangka yang diberikan sosiolog agama, Martin E. Marty, dengan beberapa modifikasi, agaknya cukup relevan diterapkan untuk melihat gejala "kekerasan atas nama agama". Menurutnya, ciri yang utama adalah

14 Muhammad Ali, Teologi Pluralis-Multikultural (Jakarta: Kompas, 2003), 119.

15 J.B. Banawiratma, "Bersama Saudara-Saudari Beriman Lain: Perspektif Gereja Katolik," in Dialog: Kritik dan Identitas Agama (Yogyakarta: Dian Interfidei, 1993), 17.

16 Azyumardi Azra, Pergolakan Politik Islam (Jakarta: Paramadina, 1996), 109.

17 Oliver Roy, The Failure of Political Islam (London: I.B. Tauris \& Co. Ltd., 1994), 2-4.

18 John L. Esposito, The Islamic Threat Myth or Reality? (Oxford: Oxford University Press, 1992), 7-8.

${ }_{19}$ Muhammad Abid Al-Jabiri, Agama, Negara dan Penerapan Syariah, Terjemah (Yogyakarta: Fajar Pustaka, 2001), 139-49. 
oppositionalism (paham perlawanan), yakni paham perlawanan terhadap ancaman yang dipandang membahayakan eksistensi agamanya, apakah dalam bentuk modernitas atau modernisme, sekularisasi, dan tata nilai Barat pada umumnya.20 Sikap melawan atau berjuang (fight) dilakukan, di antaranya dengan melawan kembali (fight back) kelompok yang mengancam keberadaan atau identitas yang menjadi tatanan hidup; berjuang untuk (fight for) menegakkan cita-cita yang meliputi persoalan hidup secara umum, seperti keluarga atau institusi sosial; berjuang dengan (fight with) kerangka nilai atau identitas tertentu yang berasal dari warisan masa lalu maupun kontruksi yang baru; berjuang melawan (fight againt) musuh-musuh tertentu yang muncul dalam bentuk komunitas atau tata sosial keagamaan yang dipandang menyimpang; dan terakhir, mereka melakukannya dalam kerangka perjuangan atas nama (fight under) Tuhan. ${ }^{21}$

Adapun latar munculnya radikalisme secara sosiologisempiris tidak dapat dipisahkan dari dinamika internal masyarakat itu sendiri. Hal tersebut dilatarbelakangi oleh adanya sejumlah faktor yang melingkupinya baik internal maupun eksternal.

Gejala radikalisme di dunia Islam bukan fenomena yang datang tiba-tiba. Ia lahir dalam situasi politik, ekonomi, dan sosial budaya yang oleh pendukung gerakan Islam radikal dianggap sangat memojokkan umat Islam. Secara politik umat Islam bukan saja tidak diuntungkan oleh sistem, tetapi juga merasa diperlakukan tidak adil. Mereka merasa aspirasi mereka tidak terakomodasi dengan baik karena sistem politik yang dikembangkan adalah sistem kafir yang dengan sendirinya lebih memihak

20 Azra, Pergolakan Politik Islam, 109.

${ }^{21}$ Effendi dan Prasetyo, Radikalisme Agama, xix. 
kalangan nasionalis sekuler ketimbang umat Islam itu sendiri.

Menurut Gus Dur,22 lahirnya kelompok-kelompok garis keras atau radikal tersebut tidak bisa dipisahkan dari dua sebab utama, yaitu: Pertama, para penganut Islam garis keras tersebut mengalami semacam kekecewaan dan alienasi karena "ketertinggalan" umat Islam dari kemajuan peradaban Barat dan penetrasi budayanya dengan segala eksesnya. Karena ketidakmampuan mereka untuk mengimbangi dampak materialistik budaya Barat, akhirnya mereka menggunakan kekerasan untuk menghalangi ofensif matrealistik dan penetrasi Barat.

Kedua, kemunculan kelompok-kelompok Islam garis keras itu tidak terlepas dari karena adanya pendangkalan agama dari kalangan ummat Islam sendiri, khususnya angkatan mudanya. Pendangkalan itu terjadi karena mereka yang terpengaruh atau terlibat dalam gerakangerakan Islam radikal atau garis keras umumnya terdiri dari mereka yang berlatar belakang pendidikan ilmu-ilmu ekstakta dan ekonomi. Latar belakang seperti itu menyebabkan fikiran mereka penuh dengan hitunganhitungan matematik dan ekonomis yang rasional dan tidak ada waktu untuk mengkaji Islam secara mendalam. Mereka mencukupkan diri dengan interpretasi keagamaan yang didasarkan pada pemahaman secara literal atau tekstual. Bacaan atau hafalan mereka terhadap ayat-ayat suci AlQur'an dan Hadits dalam jumlah besar memang mengagumkan. Tetapi pemahaman mereka terhadap substansi ajaran Islam lemah, karena tanpa mempelajari pelbagai penafsiran yang ada, kaidah-kaidah ushul figh, maupun variasi pemahaman terhadap teks-teks yang ada.

22 Islamku, Islam Anda, Islam Kita, Kata Pengantar (Jakarta: Wahid Insitut, 2006). 
Pandangan ini agaknya sejalan dengan studi radikalisme tentang latar belakang munculnya faham radikalisme di Indonesia. Menurut Azyumardi bahwa muncul dan berkembangnya radikalisme di Indonesia disebabkan oleh dua faktor utama, yaitu: Pertama, faktor internal umat Islam, yakni adanya penyimpangan normanorma agama yang akibat dari penyimpangan tersebut dsebabkan oleh adanya kehidupan sekuler yang telah merasuki umat Islam melakukan gerakan kembali kepada otentitas Islam, sikap ini ditopang oleh pemahaman agama ang totalitas dan formalistik, bersikap kaku dalam memahami teks agama secara literal. Karena itu, identitas keagamaannya bersifat literalistik, kaku dan cenderung menolak perubahan sosial. Sehingga pada gilirannya mereka frustasi terhadap perubahan dunia yang begitu cepat, sementara respon Islam sangat lambat dan ketingalan di bandingkan masyarakat Barat-sekuler. Konsep-konsep modern seperti demokrasi, HAM sebagai produk Barat mereka tolak secara radikal.

Kedua, faktor eksternal umat Islam, yakni adanya sikap refresif penguasa terhadap kelompok Islam seperti yang dilakukan oleh Orde Baru yang telah membangkitkan radikalisme Islam. Di samping itu, adanya krisis kepemimpinan yang terjadi pasca Orde Baru yang ditunjukkan dengan lemahnya penegakkan hukum dan telah mendorong gerakan Islam untuk menerapkan syariat Islam sebagai solusi krisis tersebut. Ini menunjukkan kemunculan radikalisme Islam dijadikan jawaban atas lemahnya aparat penegak hukum dalam menyelesakan kasus yang terkait dengan umat Islam. ${ }^{23}$

23 Azyumardi Azra, "Mereka Mengambil Alih Dalam Penegakan Hukum," Republika, n.d., 2002 edisi, sec. Khazanah Suplemen Republika, 4-5. 
Lebih jauh, pengaruh radikalisme agama dapat melahirkan radikalisasi gerakan keagamaan yang menurut Endang Turmudzi akibat adanya kenyataan dari menguatnya fundamentalisme keberagamaan para pemeluknya yang disebabkan oleh keinginan kuat untuk mempraktekkan doktrin ajaran agamanya yang dalam bentuk gambaran masyarakat ideal dan tantangan realitas domestik umat dalam negeri dan konstelasi politik internasional yang dinilai memojokkan dan merusak kehidupan sosial politik umat Islam. ${ }^{24}$

Sementara Dahrendorf menyebutkan tiga kondisi yang mendukung kemunculan struggle group dan seringkali menjadi pendorong terjadinya konflik, yakni komunikasi terus-menerus di antara orang-orang senasib; (2) adanya seorang pemimpin yang membantu mengartikulasikan ideologi, mengorganisasikan kelompok, dan memformulasikan rencana untuk melakukan tindakan kelompok; dan (3) legitimasi kelompok di mata komunitas yang lebih luas - atau setidak-tidaknya tidak ada tekanan komunitas yang efektif terhadap kelompok. ${ }^{25}$

Dengan demikian, kemunculan gerakan radikalisme secara sporadis di berbagai belahan dunia tidak muncul dari ruang kosong. Kenyataan yang muncul di tengah masyarakat saat ini adalah sikap gegabah kebanyakan orang yang menuduh Islam sebagai biang keladi munculnya gerakan radikalisme dan terorisme. Hanya karena ada sebagian kelompok melakukan tindakan radikalisme dan terorisme, Islam pun kemudian distigmatisasi sebagai ancaman bagi ketentraman dan kedamaian dunia. Mereka yang tidak memiliki pemahaman yang benar tentang Islam, akan sangat mudah menerima

24 Turmudzi dan Sihbudi, Islam dan Radikalisme di Indonesia, $1-8$.

${ }^{25}$ Ibid. 
pandangan dan stigma negatif tersebut. Oleh karena itu, perlu diupayakan sebuah tindakan nyata berupa sosialisasi ajaran Islam yang damai dan moderat sebagai spirit perdamaian.

Lahirnya berbagai kekacauan yang mengguncang tatanan dunia saat ini, sesungguhnya tidak adil jika diasumsikan sebagai upaya "fundamentalisme Islam" untuk mengkonstruksi satu tatanan dunia baru sebagai pengganti tatanan dunia Barat. Sangat tidak fair jika memposisikan Islam sebagai biang keladi berbagai kekacauan, radikalisme, atau terorisme yang ada saat ini. Siapapun yang ingin mengidentifikasi dan menganalisis berbagai gejala raadikalisme dan terorisme harus mampu membedakan antara Islam sebagai sebuah agama dengan Islam sebagai ideologi politik. Islam sebagai agama dan peradaban adalah satu hal, sedangkan Islam sebagai ideologi politik adalah hal lain. Menyamakan keduanya adalah tindakan gegabah, sekaligus menunjukkan ketidakpahaman terhadap Islam.

Ideologi, apapun bentuknya, adalah kekuatan penggerak yang mendekonstruksi setiap tatanan kehidupan yang statis dan pembebas dari setiap bentuk ketertindasan yang menimpa manusia. Ali Shari'ati secara apik menguraikan hubungan antara agama dengan ideologi dan sisi yang menjadi pembeda antara keduanya. Menurutnya, agama pada dasarnya terdiri dari dua macam. Jenis pertama adalah agama sebagai ideologi, sedangkan jenis yang kedua adalah agama sebagai kumpulan tradisi, konvensi sosial, atau sebagai semangat kolektif suatu kelompok. ${ }^{26}$

${ }^{26}$ Ali Shari'ati, Ideologi Kaum Intelektual: Suatu Wawasan Islam, ed. oleh Syafiq Basri dan Haidar Bagir, 5 ed. (Bandung: Mizan, 1993), 80. 
Tindakan aksi radikalisme dan terorisme yang dilakukan oleh para radikalis dan teroris selalu menjustifikasi gerakannya sebagai bentuk jihad. Hal ini adalah kesalahan yang sangat fundamental. Karena konsep jihad sendiri tidak dipahami secara holistik dan komprehensif. Pertanyaan penting yang dapat diajukan kepada peganjur radikalisme atau terorisme adalah apakah benar tindakan mereka itu jihad seperti yang dianjurkan oleh Islam? Jangan-jangan para teroris yang mengaku berjihad itu tidak memahami makna jihad yang sebenarnya. Mereka hanya tahu kulitnya saja, tanpa mengetahui isinya. Lebih berbahaya lagi, kalau ternyata apa yang mereka sebut sebagai jihad itu ternyata adalah upaya penyelewengan nash al-Qur' an dan hadis.

Dalam al-Qur'an dan hadis memang terdapat beberapa ayat dan matan hadis yang memerintahkan umat Islam untuk berjihad. Namun demikian, ayat dan matan hadis yang berkaitan dengan konsep jihad atau peperangan seringkali ditafsirkan secara serampangan. Penafsiran secara subyektif dan jauh dari ilmiah inilah yang kemudian menjadi justifikasi sekaligus stimulus bagi banyak gerakan (harakah) politik Islam yang pada gilirannya justru menstigma wajah umat Islam secara keseluruhan.

Dari sinilah kemudian muncul gerakan-gerakan yang mempolitisir agama yang pada hakekatnya bertentangan dengan substansi agama itu sendiri. Oleh karenanya, fenomena radikalisme agama, sekali lagi, jangan dipahami terjadi karena ajaran agama yang salah, melainkan karena pemahaman yang keliru terhadap konsep ajaran agama (baca:jihad) dan karena faktor lain, seperti sosial, ekonomi dan politik. Pemahaman agama juga tidak bisa berdiri sendiri. Faktor sosial, lingkungan, pendidikan dan politik ikut andil dalam mempengaruhi pemahaman keagamaan seseorang. 
Dari kedudukannya inilah, agama dinilai memiliki fungsi manifes (manifest functions) yaitu fungsi yang disadari betul oleh para partisipan sebagai manifestasi objektif dari suatu sistem sosial, misalnya meningkatkan kehesivitas umat (Ukuwah islamiyah), atau memiliki fungsi laten (latent functions) ${ }^{27}$ yaitu fungsi yang tidak dikehendaki secara sadar dari sistem sosial tersebut dalam memunculkan radikalisme, atau menurut Azyumardi Azra agama merupakan lahan empuk untuk menjadi crying banner dalam melakukan tindakan anarkis (radikalismePenulis), ${ }^{28}$ yang juga sama-sama didasari pada pembacaan dan konstruksi tekstualitas yang ada dalam agama itu sendiri.

Dalam konteks ini, agama memiliki dua sisi yang bertentangan sekaligus. Di satu sisi, agama mempunyai kekuatan yang luar biasanya dalam menyatukan manusia dari berbagai latar belakang etnik budaya, tapi di sisi lain pemahaman keagamaan yang subyektif juga menjadi potensi pemicu tindakan radikalisme. Di sinilah terlihat betapa pemahaman agama bisa mendorong tindakan radikalisme dan aksi terorisme yang pada gilirannya dapat merusak harmoni sosial.

\section{Telaah Ayat-ayat Jihad dan Qital}

Jihad merupakan satu istilah yang banyak menimbulkan pemahaman kontroversial dalam masyarakat. Karena kata jihad seringkali dihubungkan dengan gerakan kelompok radikalisme. Kata jihad seolaholah sudah berkonotasi negatif, karena agama sering dijadikan legitimasi aksi kekerasan oleh para

${ }^{27}$ Robert K. Merton, On Theoritical Sociology (New York: The Pree Pres, 1967), 114-115.

28 Azyumardi Azra, Menuju Masyarakat Madani: Gagasan, Fakta dan Tantanga (Bandung: Remaja Rosda Karya, 1999), 11. 
pengusungnya melalui penafsiran yang distorsif. Memonopoli penafsiran agama membawa implikasi destruktif pada tataran kehidupan masyarakat, sehingga muncul kesan makna yang telah "dibajak" penafsiranya itu telah menjadi arus utama kehidupan beragama. Padahal, misi suci agama tidak sama dengan yang diekspresikan oleh para pelaku kekerasan yang selama ini selalu bersandar pada pengertian jihad. Bagaimana mestinya jihad dimaknai?

Secara etimologi, term Jihad berasal dari kata jahadayajhadu-juhd/jahd. Para ahli linguistik membedakan definisi jahd dan juhd. Mereka memaknai term juhd dengan "kemampuan" (thâqah), sedangkan jahd dengan "rintangan" (masyaqqah). Jika dikatakan jahada fi al-amr, berarti ia akan bersungguh-sungguh dalam urusan tersebut, sehingga merasa lelah karena berusaha semaksimal mungkin untuk memperolehnya. Sedangkan kata juhd juga dapat dipahami sebagai upaya seseorang untuk tetap bertahan hidup dalam keterbatasannya. ${ }^{29}$

Sa'id al-Asymawi berpendapat bahwa jihad adalah berupaya secara sungguh-sungguh dengan mengerahkan segala kemampuan (badzl al-juhd) untuk mencapai tujuan tertentu. Bersabar dalam keletihan (tahammul al-jahd) ketika menjalankan satu perbuatan atau merealisasikan sebuah misi. $^{30}$

Dari aspek terminologis, definisi jihad berkisar kepada tiga aspek: pertama, jihad yang dipahami secara umum, yaitu segala kemampuan yang dicurahkan oleh manusia dalam mencegah atau membela diri dari marabahaya dan pada saat yang sama menegakkan kebenaran. Kedua, jihad

${ }^{29}$ Ibn Manzhûr, Lisân al-'Arab, I (Kairo: Dâr al-Ma'ârif, n.d.), 708-9.

30 Sa'îd al-Asymâwî, al-Islâm al-Siyâsî (Kairo: Sînâ li al-Nasyr, 1992). 
dipahami secara khusus, yaitu mencurahkan segenap upaya dalam menyebarkan dan membela dakwah Islam. Ketiga, jihad yang dibatasi pada arti perang (qitâl) membela agama untuk menegakkan eksistensi agama dan proteksi dalam kegiatan dakwah. ${ }^{31}$

Berdasarkan elaborasi tersebut, terlihat bahwa ayatayat al-Qur'an yang sering kali disalahpahami dan dijadikan dalil bagi tindakan-tindakan radikal adalah ayatayat jihad dan ayat-ayat perang (qital). Karena itu, menjadi penting untuk memahami kedua istilah tersebut sesuai dengan konteks dan maksud pensyariatannya.

Ibn Rusyd ${ }^{32}$ membagi jihad menjadi empat macam; jihad dengan hati, jihad dengan lidah, jihad dengan tangan, dan jihad dengan pedang. Artinya, bagi Ibn Rusyd, term jihad dipahami dalam arti perang, hanya merupakan salah satu makna saja, bukan seluruh makna. Sedangkan jihad menurut Wahbah al-Zuhaily, adalah mengeluarkan segenap kemampuan dan kekuatan dalam memerangi orang kafir dan menolaknya dengan jiwa, harta dan lisan. Oleh karenanya, jihad menurutnya dapat ditempuh dengan metode pengajaran hukum-hukum Islam dan menyebarluaskannya di kalangan manusia, atau dengan cara mengeluarkan harta, serta juga dengan cara bekerja sama dalam hal memerangi musuh apabila pemimpin/ penguasa sudah mengumumkan jihad (perang). ${ }^{33}$

Jihad adalah cara untuk mencapai tujuan. Jihad tidak mengenal putus asa, menyerah, kelesuan, tidak pula pamrih. Tetapi jihad tidak dapat dilaksanakan tanpa modal,

${ }^{31}$ Husni Adhâm Jarrâr, al-Jihâd al-Islâmiy al-Mu'âshir: FiqhuhHarakâtuh-A'lâmuh ('Amân: Dâr al-Basyar, 1994), 11.

32 Ibn Rusyd, Bidayah al-Mujtahid wa Nihayah al-Muqtashid, Juz I (Kairo: Maktabah al-Kulliyat al-Azhariyah, 1989), 651-95.

33 Wahbah al-Zuhaily, al-Figh al-Islamy wa Adilatuhu, Juz 3 (Damaskus: Dar al-Fikr, 2008), 712. 
karena itu jihad mesti disesuaikan dengan modal yang dimiliki dan tujuan yang ingin dicapai. Sebelum tujuan tercapai dan selama masih ada modal, selama itu pula jihad dituntut. ${ }^{34}$

Kemudian Moenawir Syadzali mengatakan "di Indonesia orang tidak mesti mati demi Islam, yang kita butuhkan sekarang adalah orang-orang yang mau hidup demi Islam. Di Indonesia, jihad konflik bersenjata telah usai dan tidak membutuhkan lagi perjuangan bersenjata, jihad harus dilakukan secara damai dan bentuk-bentuk lainnya tidak dapat ditoleransi." 35

Dari beberapa definisi yang dikemukakan oleh para ulama di atas, menunjukkan bahwa jihad mempunyai arti yang luas serta tujuan yang ingin dicapainya. Secara umum tujuan jihad adalah menegakkan agama Allah di permukaan bumi. ${ }^{36}$ Dengan berorientasi kepada tujuan tersebut, maka jihad dapat dinilai sebagai ibadah kepada Allah yang didasarkan kepada kesungguhan dengan cara mengerahkan seluruh kemampuan yang dimiliki baik dengan nyawa, harta, pikiran, lisan dan lainnya.

Dalam Al-Qur'an kata jihad dalam berbagai bentuknya disebutkan sebanyak 41 kali. Sebagian besar dari ayat-ayat yang menggunakan kata jihad mengandung pengertian sebuah perjuangan yang berat, mengerahkan segenap kemampuan untuk meraih suatu tujuan. Selain itu ada beberapa ayat al-Qur'an yang memiliki pengertian bahwa jihad adalah perang dengan angkat senjata. Term Jihad

${ }^{34}$ M. Quraish Shihab, Wawasan Al-Qur'an (Bandung: Mizan, 1991), 505.

35 Ihsan Ali Fauzi, Jalan Baru Islam; Memetakan Paradigma Mutakhir Islam Indonesia (Bandung: Mizan, 1998), 247.

36 Muhammad Chirzin, Jihad Dalam Al-Qur'an; Telaah Normatif, Historis dan Prospektif (Yogyakarta: Mitra Pustaka, 1997), 50. 
yang diartikan perang lebih banyak disebutkan dengan kata "qital". Jadi, term jihad memiliki dua pengertian; pertama jihad berarti berusaha keras dengan semua kemampuan untuk mencapai tujuan tertentu. Dan kedua; jihad diartikan dengan perang mengangkat senjata. Ayat alQur'an tentang jihad yang turun pada periode Madinah, kebanyakan berhubungan dengan perang.

Hanya saja, tidak semua ayat-ayat jihad menunjukkan perang, misalnya ayat jihad yang diturunkan di Mekkah, sebagai berikut QS. Luqman ayat 15

Ayat di atas merupakan salah satu contoh bahwa kata jihad isinya tidak berhubungan dengan masalah perang saja. Bahkan Ibnu Katsir menafsirkan ayat ini dengan kalimat "jika keduanya sangat berkeinginan......." (in harashaa 'alaika kulla al hirsh).

Lafaz yang sama terdapat pada surat Al-Ankabut ayat 8 (jahadaka) yang ditafsirkan Ibnu Katsir dengan ungkapan, "harashaa 'alaika" (keduanya mendesak kamu). Sekali lagi, ayat al-Qur'an ini bukan diartikan perang, tetapi adalah sebuah usaha keras disertai paksaan. Karena jika ayat ini diartikan dengan perang, tidak sesuai dengan kandungan ayatnya.

Adapun ayat lain yang mengandung ajaran jihad disebutkan dengan lafadz qital Q.S. Al-Taubah ayat 123 . Ayat ini menegaskan, pengertian qital adalah perang di jalan Allah SWT dengan memerangi orang-orang kafir. Walhasil, jihad sebagai ajaran Islam yang mulia dapat dilaksanakan dengan berbagai macam cara. Ketika umat Islam diserang dan ditindas maka jihad yang berlaku adalah perang dengan angkat senjata. Namun jika dalam kondisi yang aman dan damai maka jihad yang harus dilakukan adalah dakwah dengan hikmah, beramal shaleh, melakukan ibadah-ibadah, menuntut ilmu, membantu orang lemah dan berbakti kepada orang tua, dan lain-lain. 


\section{Deradikalisasi Pemahaman Keagamaan}

Secara etimologis deradikalisasi terbentuk dari akar kata radikal yang diawali awalan de yang dalam bahasa inggris berarti melenyapkan, menghilangkan atau menghapus sesuatu. Dengan demikian, deradikalisasi dapat diartikan sebagai upaya melenyapkan, menghilangkan atau menghapus tindakan radikal. Dari tinjuan etimologis di atas, secara terminologis deradikalisasi pemahaman keagamaan berarti upaya menghapuskan pemahaman yang radikal terhadap ayat-ayat al-Qur' an dan Hadis, khususnya ayat atau hadis yang berkaitan dengan konsep jihad, perang, dar al-harbi dan seterusnya. Dengan demikian, deradikalisasi bukan dimaksudkan sebagai upaya untuk menyampaikan "pemahaman baru" tentang Islam, melainkan sebagai upaya mengembalikan dan meluruskan kembali pemahaman ajaran Islam secara holistik dan kontekstual sesuai dengan misi utamanya sebagai desiminasi ajaran rahmatan lil 'alamin dan spirit perdamaian dunia.

Berdasarkan definisi di atas dan juga cakupan kerjanya maka deradikalisasi diharapkan bukan hanya menjadi tugas pemerintah, namun menjadi tugas semua pihak di dalam wilayah negara, masyarakat sipil dan juga kalangan bisnis.

Pada dasarnya, setiap agama mengajarkan umatnya untuk berlaku kasih dan sayang terhadap sesamanya. Pesan mendasar dari setiap agama yang ada di muka bumi adalah hidup secara damai dengan seluruh makhluk ciptaan Tuhan. Tidak ada satupun agama yang mengajarkan pemeluknya untuk bertindak radikal, anarkis dan menyebarkan teror. Kalaupun kemudian agama tertentu, dituduh sebagai agama yang mengajarkan radikalisme dan terorisme karena adanya ayat-ayat dan hadis tentang perang, maka yang harus dikoreksi atau dikritik bukanlah ayat al-Qur'an atau hadisnya, tetapi pemahaman manusia yang membaca dan menafsirkan ayat-ayat tersebut. 
Validitas dan otentisitas al-Qur'an dan Hadis sebagai sumber hukum sekaligus sebagai landasan etika dan moral tidak pernah diragukan oleh setiap Muslim. Namun demikian, ketika memasuki wilayah penafsiran, faktor subjektivitas dari masing-masing penafsir tentu akan menjiwai pandangannya terhadap sebuah ayat atau hadis. Oleh karena itu, wajar jika kemudian kita menemukan tafsiran yang berbeda dari beberapa kitab tafsir tentang sebuah ayat atau hadis. Faktor sosio-politis juga dapat mempengaruhi pandangan seseorang terhadap kandungan ayat al-Qur'an dan hadis. Syaikh Nawawi al-Bantani, misalnya, dalam kitab tafsirnya yang terkenal, Marah Labid, ketika menafsirkan ayat-ayat al-Qur'an tak pelak dipengaruhi oleh situasi tanah airnya ketika dijajah oleh Belanda. ${ }^{37}$ Ini menunjukkan ketika memasuki wilayah (domain) tafsir, pemahaman seorang mufassir amat dipengaruhi oleh berbagai aspek yang melingkupinya.

Berkaitan dengan pendekatan agama dalam upaya deradikalisasi ini, ada baiknya kita mengingat kembali pesan dari Rasulullah SAW. Dalam sebuah kesempatan, beliau menyampaikan bahwa umatnya tidak akan sesat selama mereka berpedoman kepada dua warisannya yang paling berharga, yaitu al-Qur'an dan as-Sunnah. Dalam sebuah hadis Rasulullah SAW bersabda:

Dengan mempertimbangkan pesan Rasulullah di atas, maka umat Islam semestinya mendasari setiap aktivitas kehidupannya dengan nilai-nilai al-Qur'an dan hadis yang mengandung prinsip-prinsip etika dan moral yang dapat dijadikan acuan dalam bertindak. Fazlur Rahman, intelektual neo-modernis asal Pakistan, dalam bukunya berjudul Islam menyatakan bahwa meskipun al-Qur'an

37 Mamat S. Burhanuddin, Hermeneutika al-Qur'an ala Pesantren: Analisis terhadap Tafsir Marah Labid karya KH. Nawawi Banten (Yogyakarta: UII Press, 2006), 41. 
mengandung beberapa aturan-aturan hukum yang penting, namun semangat dasar dari al-Qur'an adalah prinsipprinsip dan seruan moral bukan hukum. ${ }^{38}$ Dengan statement ini, Rahman ingin nampaknya ingin menegaskan bahwa selain metode legislasi, lebih luas al-Qur'an juga memuat aturan-aturan moral dan etika yang semestinya harus mendapatkan perhatian lebih ketimbang ayat-ayat hukum.

Lebih jauh, Rahman menawarkan prosedur dalam upaya memahami al-Qur'an; pertama, seseorang harus mengkaji al-Qur'an dalam ordo historis untuk mengapresiasi tema-tema dan gagasan-gagasannya. Jika tidak, besar kemungkinan ia akan tersesat dalam memahami beberapa butir penting tertentu dari ajarannya. Kedua, seseorang harus mengkajinya dalam latar belakang sosio-historisnya. Tanpa melihat latar belakang mikro dan makronya secara memadai, seseorang bisa jadi akan salah tangkap terhadap elan dan maksud al-Quran serta aktivitas Nabi, baik di Makkah maupun di Madinah. ${ }^{39}$

Prosedur yang ditawarkan Rahman, sejatinya juga banyak ditawarkan oleh ilmu tafsir klasik, dan relevan untuk diterapkan dalam agenda deradikalisasi pemahaman keagamaan ini. Aspek asbab al-nuzul atau latar belakang historis turunnya sebuah ayat, dan aspek asbab al-wurud sebuah hadis, harus menjadi acuan dalam memahami maksud dan tujuan ayat dan hadis tersebut.

Demikian demikian, cita-cita moral ideal Islam adalah membangun dunia, dimana orang Islam maupun non-Islam hidup bersama menikmati keadilan, kedamaian, kasih sayang dan keharmonisan. Inilah tantangan dalam

38 Fazlur Rahman, Islam, alih bahasa Ahsin Mohammad (Bandung: Pustaka, 1997), 36 dan 43.

39 Ahmad Syafi'ii Ma'arif, "Fazlur Rahman, Al-Qur'an dan Pemikiran Islam: Sebuah Pengantar," in Islam, alih bahasa Ahsin Mohammad (Bandung: Pustaka, 1997), viii. 
kehidupan global saat ini, sekaligus tugas semua elemen masyarakat, terutama pemimpin agama, intelektual, akademisi dan elit politik untuk menangkap pesan-pesan moral agama yang dapat membawa kepada kehidupan yang harmonis di tengah kehidupan bangsa yang plural.

Dilihat dari sisi manapun, tindakan anarkis, radikal dan destruktif yang sering ditunjukkan sebagian kelompok radikal bertentangan secara diametral dengan prinsipprinsip Islam. Secara fundamental, Islam meletakkan aspek kerahmatan sebagai fondasi keberagamaan, dan sangat menghargai nilai-nilai spiritualitas dan intelektualitas, serta suasana dialogis yang harmonis.

Oleh karena itu, implikasi psikologis dari radikalisme agama dan kekerasan sejenisnya hanya akan menjadikan Islam tereduksi sebagai bayang-bayang menakutkan yang kehilangan aspek kemanusiaannya. Kesyahduan beragama lalu berbias menjadi keberingasan, dan pencerahan tersungkur menjadi keangkuhan. Keberagamaan yang sejatinya dikembangkan di atas kecerdasan emosi dan nalar argumentatif berkembang menjadi kekuatan destruktif, berwujud dentuman bom, tumpahan darah dan kematian yang tidak akan memberi dampak penyadaran dan transformasi nilai-nilai moral luhur Islam.

\section{E. Simpulan}

Munculnya radikalisme agama dilatarbelakangi oleh berbagai faktor yang sangat kompleks dan pelik. Salah satunya adalah pada aspek pemahaman terhadap ajaran fundamen Islam yang bersifat literal-skriptural, rigid dan cenderung mengarah pada klaim kebenaran. Ciri utama ini berkaitan dengan pemahaman dan interpretasi mereka terhadap doktrin jihad misalnya, yang cenderung bersifat rigit dan literalis.

Ideologi kekerasan atas nama jihad sering dijadikan legitimasi aksi kekerasan oleh para pengusungnya melalui 
penafsiran yang distortif. Monopoli penafsiran agama membawa implikasi destruktif pada tataran kehidupan masyarakat, sehingga muncul kesan ajaran Islam "yang dibajak penafsiranya" itu telah menjadi arus utama kehidupan beragama. Padahal, misi suci Islam tidak sama dengan yang diekspresikan oleh para pelaku kekerasan yang selama ini selalu bersandar pada pengertian jihad.

Ideologi radikalisme sering dijadikan legitimasi aksi kekerasan oleh para pengusungnya melalui penafsiran makna jihad yang distortif. Monopoli penafsiran ini membawa implikasi destruktif pada tataran kehidupan masyarakat, sehingga muncul kesan bahwa penafsiran itu telah menjadi arus utama kehidupan beragama. Padahal, misi suci Islam tidak sama dengan yang diekspresikan oleh para pelaku radikalisme yang selama ini selalu bersandar pada makna jihad. Oleh karenanya, pada konteks inilah harus dilakukan upaya deradikalisasi pemahaman keagamaan. Para intelektual Muslim moderat harus tampil bersuara (speak out) untuk membebaskan makna jihad dari tirani kognitif-epistemologis yang sempit, literal dan parsial, dengan mengabaikan aspek sejarah, sosial dan politik serta rasionalitas yang melatarbelakangi turunnya ayat (asbâb an-nuzĥul) dan munculnya hadis (asbâb al-wurud). Dengan demikian, upaya deradikalisasi pemahaman keagamaan adalah keniscayaan dan diharapkan sinergi umat Islam di seluruh dunia untuk menghadirkan wajah Islam yang ramah dan moderat sebagai orientasi gerakan perubahan yang damai dan mashlahah[.]

\section{REFERENSI}

Ali, Muhammad. Teologi Pluralis-Multikultural. Jakarta: Kompas, 2003.

Al-Jabiri, Muhammad Abid. Agama, Negara dan Penerapan Syariah. Terjemah. Yogyakarta: Fajar Pustaka, 2001. 
Asymâwî, Sa'îd al-. al-Islâm al-Siyâsî. Kairo: Sînâ li al-Nasyr, 1992.

Azra, Azyumardi. Menuju Masyarakat Madani: Gagasan, Fakta dan Tantanga. Bandung: Remaja Rosda Karya, 1999.

- - -. "Mereka Mengambil Alih Dalam Penegakan Hukum." Republika. n.d., 2002 edisi, sec. Khazanah Suplemen Republika.

- - - . Pergolakan Politik Islam. Jakarta: Paramadina, 1996.

Banawiratma, J.B. "Bersama Saudara-Saudari Beriman Lain:

Perspektif Gereja Katolik." In Dialog: Kritik dan Identitas Agama. Yogyakarta: Dian Interfidei, 1993.

Chirzin, Muhammad. Jihad Dalam Al-Qur'an; Telaah

Normatif, Historis dan Prospektif. Yogyakarta: Mitra Pustaka, 1997.

Departemen Pendidikan dan Kebudayaan. “Kamus Besar Bahasa Indonesia." Jakarta: Balai Pustaka, 1995.

Echols, John M., dan Hassan Shadily. "Kamus Inggris Indonesia." Jakarta: Gramedia, 1995.

Effendi, Bahtiar, dan Hendro Prasetyo, ed. Radikalisme Agama. Jakarta: PPIM-IAIN, 1998.

Esposito, John L. The Islamic Threat Myth or Reality? Oxford:

Oxford University Press, 1992.

Fauzi, Ihsan Ali. Jalan Baru Islam; Memetakan Paradigma Mutakhir Islam Indonesia. Bandung: Mizan, 1998.

Hanafi, Muchlis M. "Konsep al-Wasathiyyah dalam Islam."

Harmoni: Jurnal Multikultural dan MultireligiusJurnal Multikultural dan Multireligius Puslitbang Kehidupan Keagamaan Badan Litbang dan Diklat Departemen Agama RI Jakarta VIII, no. 32 (Oktober-Desember 2009).

Islamku, Islam Anda, Islam Kita. Kata Pengantar. Jakarta: Wahid Insitut, 2006.

Jarrâr, Husni Adhâm. al-Jihâd al-Islâmiy al-Mu'âshir: FiqhuhHarakâtuh-A'lâmuh. 'Amân: Dâr al-Basyar, 1994. 
Juergensmeyer, Marx. Teror Atas Nama Tuhan: Kebangkitan Global kekerasan Agama. Jakarta: Nizam Press \& Anima Publishing, 2002.

Lajnah Pentashihan Mushaf al-Qur'an Kementerian Agama. Tafsir al-Qur'an Tematik. Jilid I. Jakarta: Kamil Pustaka, 2014.

Ma'arif, Ahmad Syafi'ii. "Fazlur Rahman, Al-Qur'an dan Pemikiran Islam: Sebuah Pengantar." In Islam, alih bahasa Ahsin Mohammad. Bandung: Pustaka, 1997.

Makruf, Djamhari. "Radikalisme Islam di Indonesia; Fenomena Sesaat?" In Agama dan Radikalisme di Indonesia. Jakarta: Huqtah, 2007.

Mamat S. Burhanuddin. Hermeneutika al-Qur'an ala Pesantren: Analisis terhadap Tafsir Marah Labid karya KH. Nawawi Banten. Yogyakarta: UII Press, 2006.

Manzhûr, Ibn. Lisân al-'Arab. I. Kairo: Dâr al-Ma'ârif, n.d.

M. Quraish Shihab. Wawasan Al-Qur'an. Bandung: Mizan, 1991.

Merton, Robert K. On Theoritical Sociology. New York: The Pree Pres, 1967.

Rahman, Fazlur. Islam, alih bahasa Ahsin Mohammad. Bandung: Pustaka, 1997.

Rodin, Dede. "Islam dan Radikalisme: Telaah atas Ayatayat 'kekerasan' dalam al-Qur'an." Jurnal ADDIN 10, no. 1 (2016).

Roy, Oliver. The Failure of Political Islam. London: I.B. Tauris \& Co. Ltd., 1994.

Rusyd, Ibn. Bidayah al-Mujtahid wa Nihayah al-Muqtashid. Juz

I. Kairo: Maktabah al-Kulliyat al-Azhariyah, 1989.

Shari'ati, Ali. Ideologi Kaum Intelektual: Suatu Wawasan Islam.

Diedit oleh Syafiq Basri dan Haidar Bagir. 5 ed. Bandung: Mizan, 1993.

Suito, Deny. Radikalime di Dunia Islam. Jakarta: CMM, 2005. 
Syam, Nur. "Radikalisme dan Masa Depan Hubungan Agama-Agama: Rekonstruksi Tafsir Sosial Agama." Tidak dipublikasikan, 10 Oktober 2005.

Turmudzi, Endang, dan Riza Sihbudi. Islam dan Radikalisme di Indonesia. Jakarta: LIPI Press, 2005.

Zuhaily, Wahbah al-. al-Figh al-Islamy wa Adilatuhu. Juz 3. Damaskus: Dar al-Fikr, 2008. 